\title{
FORMULASI,UJI STABILITAS DAN UJI EFEKTIVITAS ANTIOKSIDAN SEDIAAN GEL DARI EKSTRAK ETANOL DAUN SESEWANUA (Clerodendron squamatum Vahl) DENGAN MENGGUNAKAN METODE DPPH
}

\author{
Kristianus N. Runtuwene ${ }^{1)}$, Paulina V. Y. Yamlean ${ }^{1)}$, Adithya Yudistira ${ }^{1)}$ \\ ${ }^{1)}$ Program Studi Farmasi FMIPA UNSRAT Manado, 95115
}

\begin{abstract}
Chronic exposure to UV radiation on the skin can cause many side effects on the skin such as premature aging, skin cancer and decreased ability of the immune response. Irreversible skin aging begins at the age of 20 years. Mature leaves (Clerodendron squamatumVahl) have flavonoids, which are antioxidant compounds. This study aims to prove that seswanua leaf gel preparations have good stability, meet the requirements of gel preparations and have good antioxidant effectiveness. This type of research is descriptive analytics. Extraction of sesewanua leaves was carried out using maceration with $96 \%$ ethanol solvents. Evaluation of gel preparations was carried out by conducting homogeneity, organoleptic, $\mathrm{pH}$, dispersion and adhesion test. Gel stability test was carried out using the cycling test method. Testing the effectiveness of antioxidants using the method (1,1-diphenyl-2picrylhydrazyl (DPPH) with IC $C_{50}$ results of $123 \mathrm{mg} / \mathrm{L}$ for storage and $263 \mathrm{mg} / \mathrm{L}$ for post-storage. It can be concluded that gel preparations with $3 \%$ HPMC concentration have good stability, fulfills the requirements of gel preparations and has antioxidant effectiveness
\end{abstract}

Keywords : Sesewanua Leaves, Extraction, Gel Preparation, Antioxidants

\begin{abstract}
ABSTRAK
Paparan kronis radiasi UV terhadap kulit dapat menimbulkan banyak efek samping pada kulit seperti penuaan dini, kanker kulit dan penurunan kemampuan respon imun. Penuaan kulit yang bersifat irreversible dimulai pada usia 20 tahun. Daun Sesewanua (Clerodendron squamatum Vahl) memiliki senyawa flavonoid yang bersifat sebagai senyawa antioksidan. Penelitian ini bertujuan untuk membuktikan sediaan gel daun sesewanua mempunyai stabilitas yang baik, memenuhi persyaratan sediaan gel dan mempunyai efektivitas antioksidan yang bagus.Jenis penelitian ini ialah Deskriptif Analitik. Ekstraksi daun sesewanua dilakukan dengan menggunakan metode maserasi danpelarut etanol 96\%. Evaluasi sediaan gel dilakukan dengan melakuan uji homogenitas, organoleptis, $\mathrm{pH}$, daya sebar dan daya lekat. Uji stabilitas gel dilakukan dengan menggunakan metode cycling test. Pengujian efektivitas antioksidan menggunakan metode (1,1-difenil-2-pikrilhidrazil (DPPH)dengan hasil $\mathrm{IC}_{50}$ sebesar $123 \mathrm{mg} / \mathrm{L}$ untuk sebelum penyimpanan dan $263 \mathrm{mg} / \mathrm{L}$ untuk sesudah penyimpanan.. Sehingga dapat disimpulkan sediaan gel dengan konsentrasi HPMC 3\% mempunyai stabilitas yang baik, memenuhi persyaratan sediaan gel dan memiliki efektivitas antioksidan
\end{abstract}

Kata Kunci : Daun Sesewanua, Ekstraksi, Sediaan Gel, Antioksidan 


\section{PENDAHULUAN}

Paparan kronis radiasi UV terhadap terhadap kulit dapat menimbulkan banyak efek samping pada kulit, seperti penuaan dini, kanker kulit dan penurunan kemampuan respon imun. Penuaan kulit yang bersifat irreversible dimulai pada usia 20 tahun. Penuaan pada kulit merupakan suatu proses biologis kompleks yang dihasilkan dari penuaan intrinsik (dari dalam tubuh seperti genetik) dan perubahan yang berkembang seiring waktu serta dampak ekstrinsik disebabkan faktor lingkungan.(Mackiewicz dan Rimkevicius, 2008).

faktor radikal bebas merupakan teori yang sering dikaitkan sebagai penyebab faktor - faktor penuaan dini. Pembentukan radikal bebas merupakan mekanisme penting yang diterima secara luas yang menyebabkan penuaan kulit. Radikal bebas memiliki molekul reaktif sangat tinggi dengan elektron tak berpasangan yang dapat secara langsung merusak berbagai struktur membran seluler, lipid, protein dan DNA. Ketidakseimbangan ini mengarah pada kerusakan progresif struktur seluler sehingga menghasilkan penuaan yang dipercepat (Allemann \& Baumann, 2008).

Antioksidan dapat menetralkan radikal bebas dengan cara mendonorkan satu atom protonnya sehingga membuat radikal bebas stabil dan tidak reaktif (Singh, 2004). Terdapat sistem enzim superoksida dismutase yang dapat berfungsi sebagai antioksidan, namun jika jumlah radikal bebas lebih bantak dari pada enzim yang terdapat dalam tubuh maka perlu tambahan antioksidan dari luar. Berdasarkan sumbernya antioksidan terbagi menjadi dua jenis, yaitu antioksidan buatan dan antioksidan alami (Meenakshi et al., 2009).

Tanaman yang mempunyai antioksidan untuk mencegah penuaan dini (radikal bebas) dapat disajikan dalam berbagai bentuk sediaan topical seperti krim, salep dan gel. Bentuk gel mempunyai beberapa keuntungan antara lain tidak lengket, gel mempunyai aliran tiksotropik dan pseudoplastik yaitu gel berbentuk apabila disimpan dan akan segera mencair bila dikocok, konsentrasi bahan pembentuk gel yang dibutuhkan hanya sedikit untuk membentuk massa gel yang baik, viskositas gel tidak mengalami perubahan yang berarti pada suhu penyimpanan (Lieberman dkk., 1989). Gel yang mengandung antioksidan yang berasal dari alam dapat digunakan sebagai sediaan topical untuk menangkal radikal bebas.

Sesewanua

(Clerodendron squamatum Vahl.) secara empiris telah digunakan oleh masyarakat dibeberapa daerah di Sulawesi Utara. Menurut Sangi et al. (2008) daun sesewanua dianalisis mengandung alkaloid dan flavonoid. Menurut Huliselan dkk., (2015) ekstrak etil asetat daun sesewanua mengandung senyawa antioksidan yang tinggi dengan hasil $\mathrm{IC}_{50}$ sebesar 13,084 $\mathrm{mg} / \mathrm{L}$ dibandingkan dengan esktrak etanol sebesar 17,85 mg/L dan ekstrak $n$-heksan sebesar 23,737 $\mathrm{mg} / \mathrm{L}$ dengan menggunakan metode 1,1-difenil-2pikrilhidrazil (DPPH).

\section{METODOLOGI PENELITIAN}

Alat

Alat-alat yang digunakan pada penelitian ini ialah blender (Phillips), ayakan, kertas saring, pipet tetes, sudip, $\mathrm{pH}$ universal, stopwatch, oven (Ecocell MMM Group), Lemari pendingin, mixer (Philips), pipet 
mikro (ecopippette ${ }^{\mathrm{TM}}$ ), vortex (Mixer Hwashin), timbangan analitik (Ae Adam $^{\circledR}$ ), penangas (Nesco Lab), Pemberat, lumpang dan alu, allumunium foil, spektrofotometer UV-VIS (Shimadzu UV1800) dan alat - alat gelas yang biasa digunakan dilaboratorium

\section{Bahan}

Bahan - bahan yang digunakan yaitu daun Sesewanua, HPMC, etanol, propilenglikol, metil paraben, aquades dan serbuk DPPH (1,1-difenil-2-pikrilhidrazil).

\section{Pengambilan Sampel}

Sampel yang digunakan pada penelitian ini ialah daun Sesewanua yang diambil di sekitaran Desa Kembes I, Kecamatan Tombulu, Kabupaten Minahasa, Provinsi Sulawesi Utara. Sampel berupa daun sesewanua segar.

\section{Identifikasi Tanaman}

Identifikasi tanaman dilakukan di Laboratorium Taksonomi Tumbuhan, Jurusan Biologi Fakultas Matematika dan ilmu Pengetahuan Alam, Universitas Sam Ratulangi Manado.

\section{Preparasi Sampel}

Sampel berupa daun sesewanua segar masing-masing dikumpulkan dan dilakukan sortasi basah dan pencucian agar sampel terbebas dari sisa kotoran (pengotor). Setelah bersih daun ditiriskan, lalu dilakukan pengeringan dengan cara dioven dengan suhu $40^{\circ} \mathrm{C}$. Selanjutnya, sampel yang telah kering dihaluskan dengan menggunakan blender sampai menjadi serbuk, dilakukan sortasi kering dan dimasukkan didalam toples.

\section{Ekstraksi}

Sampel yang diperoleh sebanyak $500 \mathrm{~g}$ direndam dengan menggunakan larutan etanol $96 \%$ sebanyak $1.500 \mathrm{~mL}$. Metode ekstraksi dilakukan dengan cara merendam sampel dengan larutan penyari selama 3 kali 24 jam pada temperatur kamar yang dilindungi dari cahaya dan sesekali diaduk. Hasil ekstraksi kemudian disaring menggunakan kertas saring, kemudian diambil filtratnya dan residunya di remaserasi. Setelah proses ekstraksi menghasilkan 2 filtrat yang kemudian dicampur menjadi satu. Filtrat tersebut dipekatkan dengan menggunakan oven pada suhu $40^{\circ} \mathrm{C}$ untuk mendapatkan ekstrak etanol daun sesewanua.

\section{Formulasi}

Tabel 1. Formulasi standar basis gel HPMC

\begin{tabular}{ccccc}
\hline \multirow{2}{*}{ BAHAN } & \multirow{2}{*}{ FUNGSI } & \multicolumn{3}{c}{ KONSENTRASI } \\
\cline { 3 - 5 } Ekstrak Daun & Bahan & 5 & 5 & 5 \\
Sesewanua & Aktif & $53 \%$ & F3 \\
Metil Paraben & Pengawet & 0,2 & 0,2 & 0,2 \\
Propilenglikol & Humektan & 15 & 15 & 15 \\
HPMC & Geliing & 3 & 5 & 7 \\
& Agent & & & \\
Aquadest $(\mathrm{ad})$ & Pelarut & 100 & 100 & 100 \\
\hline
\end{tabular}

\section{Uji Stabilitas Gel \\ Cycling Gel}

Salah satu cara mempercepat evaluasi kestabilan dengan cycling test. Uji Cycling test ini dilakukan sebanyak 6 siklus. Sediaan gel disimpan pada suhu dingin $\pm 4^{\circ} \mathrm{C}$ selama 12 jam lalu dikeluarkan dan ditempatkan pada suhu \pm $40^{\circ} \mathrm{C}$, proses ini dihitung 1 siklus (Dewi, 2010).

\section{Evaluasi Sediaan}

\section{Uji Organoleptis}

Analisis organoleptis dilakukan dengan mengamati perubahan tekstur, 
warna, dan bau dari sediaan gel ekstrak daun Sesewanua sebelum dan sesudah cycling test. Pengamatan dilihat secara langsung bentuk, warna, dan bau dari gel yang dibuat. Gel biasanya jernih dengan konsentrasi setengah padat (Ansel, 1989).

\section{Uji Homogenitas}

Pengujian Homogenitas dilakukan dengan cara sampel gel dioleskan pada sekeping kaca atau bahan transparan lain yang cocok, sediaan harus menunjukkan susunan yang homogen dan tidak terlihat adanya butiran kasar (DepKes, 1995).

\section{Uji pH}

Penentuan $\mathrm{pH}$ sediaan dilakukan dengan menggunakan stik $\mathrm{pH}$ universal yang dicelupkan ke dalam sampel gel yang telah diencerkan. Setelah tercelup dengan sempurna, $\mathrm{pH}$ universal tersebut dilihat perubahan warnanya dan dicocokkan dengan standar $\mathrm{pH}$ universal, $\mathrm{pH}$ sediaan gel harus sesuai dengan $\mathrm{pH}$ kulit yaitu 4,56,5 (Tranggono et al., 2007).

\section{Uji Daya Sebar}

Sebanyak $0,5 \quad \mathrm{~g}$ sampel gel diletakkan diatas kaca bulat berdiameter $15 \mathrm{~cm}$, kaca lainnya diletakkan di atasnya dan dibiarkan selama 1 menit. Diameter sebar gel diukur. Setelahnya ditambahkan 150 gr beban tambahan dan didiamkan selama 1 menit lalu diukur diameter yang konstan. Menurut Garg et al. (2002), daya sebar 5-7 cm menunjukkan konsistensi semisolid yang sangat nyaman dalam penggunaan.

\section{Uji Daya Lekat}

Sebanyak 0,25 gram gel diletakkan diantara 2 gelas objek pada alat uji daya lekat, kemudian ditekan beban $250 \mathrm{~g}$ selama 1 menit, beban diangkat dan diberi beban 80 gram pada alat dan dicatat waktu pelepasan gel (Miranti, 2009).

\section{Pengujian Efektivitas Antioksidan}

Penentuan efektivitas penangkal radikal bebas DPPH menurut Burda dan Olezek (2001).Diambil sebanyak $2 \mathrm{~mL}$ larutan stok dari konsentrasi $50 \mathrm{mg} / \mathrm{L}, 100$ $\mathrm{mg} / \mathrm{L}, 150 \mathrm{mg} / \mathrm{L}, 200 \mathrm{mg} / \mathrm{L}$ dan $250 \mathrm{mg} / \mathrm{L}$, dimasukkan kedalam tabung reaksi dengan menggunakan pipet, ditambahkan masingmasing $1 \mathrm{~mL}$ larutan DPPH dalam etanol dan divorteks selama 2 menit. Berubahnya warna ungu menjadi warna kuning menunjukkan efektivitas penangkal radikal bebas. Diukur absorbansi pada spektrofotometer UV-Vis dengan panjang gelombang $517 \mathrm{~nm}$ setelah diinkubasi selama 30 menit. Setelah absorbansi didapat, aktivitas penangkapan radikal bebas (persen inhibisi) dihitung sebagai persentase berkurangnya warna DPPH dengan menggunakan rumus berikut:

$\%$ inhibisi $=1-\frac{\text { Absorbansi sampel }}{\text { Absorbansi kontrol }} \times 100 \%$

Konsentrasi sampel dan persen inhibisinya diplot masing-masing pada sumbu $\mathrm{x}$ dan $\mathrm{y}$ pada persamaan regresi linear. Persamaan tersebut digunakan untuk menentukan nilai $\mathrm{IC}_{50}$ dari masing - masing sampel dinyatakan dengan nilai y sebesar 50 dan nilai x yang akan diperoleh sebagai IC50.

\section{HASIL dan PEMBAHASAN Uji Organoleptis}

Pengujian oraganoleptis sediaan gel antioksidan ekstrak etanol daun sesewanua dengan variasi konsentrasi HPMC sebelum dan sesudah penyimpanan dimana meliputi warna, bau dan bentuk. Untuk hasilnya menunjukkan gel esktak $3 \%, 5 \%$ dan $7 \%$ mempunyai warna hijau kehitaman (pekat), bau yang harum dari sesewanua dan mempunyai bentuk/konsistensi yang lembut .semakin tinggi konsentrasi ekstra etanol daun 
sesewanua yang terkandung dalam sediaan gel antioksidan maka semakin kuat bau khas daun sesewanua sehinggah menutupi bau dari basis gel HPMC yang digunakan, serta semakin pekat warna hijau kehitaman pada sediaan gel antioksidan karna warna ekstrak etanol daun sesewanua yaitu hijau kehitaman. Pada saat penyimpanan suhu tidak mempengaruhi secara signifikan terhadap sediaan gel antioksidan ekstrak etanol daun sesewanua. Hasil ketiga konsentrasi dikatakan baik karna menurut Ansel (1989), pengamatan dilihat secara langsung bentuk, warna, dan bau dari gel yang dibuat. Gel biasanya jernih dengan konsentrasi setengah padat.

\section{Uji Homogenitas}

Hasil pengamatan homogenitas sediaan gel ekstrak etanol daun sesewanua sebelum dan sesudah penyimpanan menunjukkan hasil yang bagus dimana ketika konsentrasi ketika diamati melalui kaca preparat tidak ada partikel - partikel yang kelihatan secara kasat mata sehinggah kelihatan jernih dan homogen. Hasil ini bagus karena, sediaan harus menunjukkan susunan yang homogen dan tidak terlihat adanya butiran kasar (Anonim, 1985).

Uji pH

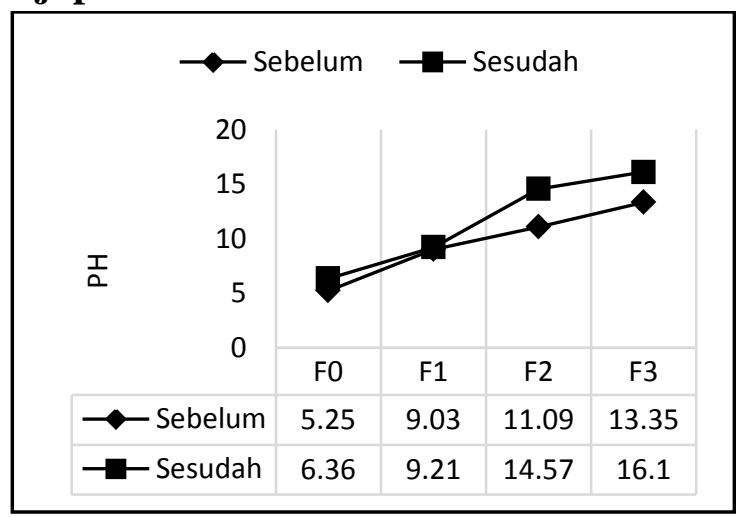

Gambar 1. Kurva Regresi Liniear Antara

Konsentrasi Sediaan Gel dan $\mathrm{pH}$.

Berdasarkan hasil pengukuran $\mathrm{pH}$ menggunakan $\mathrm{pH}$ indicator universal.
Penambahan ekstrak etanol daun sesewanua mempengaruhi $\mathrm{pH}$ dari suatu gel dikarenakan ektsrak etanol daun sesewanua mempunyai $\mathrm{pH}$ yang asam. Suhu mempunyai pengaruh terhadap sediaan gel dimana sesudah penyimpanan terjadi kenaikan $\mathrm{pH}$ dari setiap konsentrasi. Hasil pengujian $\mathrm{pH}$ gel ekstrak etanol daun sesewanua sebelum penyimpanan yaitu 5 untuk (3\%, 5\% dan 7\%) dan hasil pengujian $\mathrm{pH}$ gel ekstrak etanol daun sesewanua sesudah penyimpanan yaitu 6 (3\%, 5\% dan 7\%). $\mathrm{pH}$ gel yang terlalu asam maupun terlalu basa akan mengiritasi dan membuat kulit bersisik. Tetapi gel masih memenuhi syarat dimana sesuai dengan $\mathrm{pH}$ kulit yaitu 4,5-6,5 (Tranggono et al., 2007).

\section{Uji Daya Sebar}

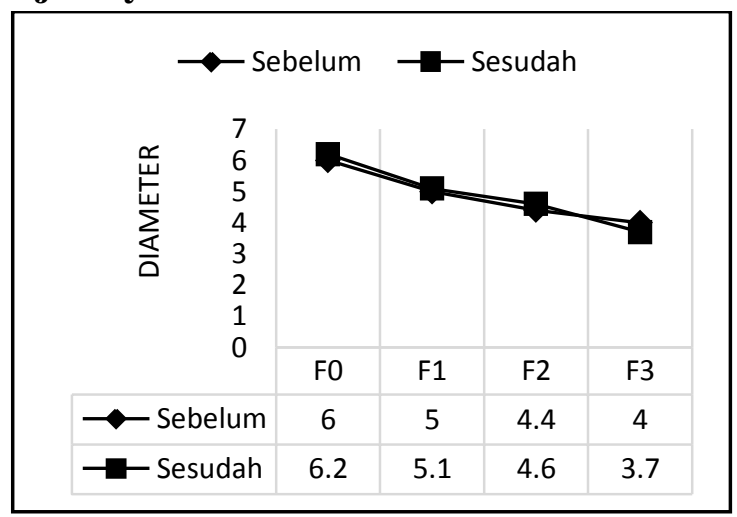

Gambar 2. Kurva Regresi Liniear Antara Konsentrasi Sediaan Gel dan Diameter Daya Sebar $(\mathrm{cm})$

Hasil uji daya sebar sediaan gel antioksidan ekstrak etanol daun sesewanua sebelum penyimpanan menunjukkan $5 \mathrm{~cm}$ untuk (3\%), 4,4 cm (5\%) dan $4 \mathrm{~cm}(7 \%)$. Untuk hasil sesudah penyimpanan yaitu 5,1 cm untuk (3\%), 4,5 cm untuk (5\%) dan 3,7 $\mathrm{cm}$ untuk (7\%). Penurunan daya sebar yang terjadi diakibatkan variasi konsentrasi HPMC yang berbeda-beda. Semakin tinggi konsentrasi HPMC daya sebar yang dihasilkan akan semakin rendah atau kecil, karena semakin tinggi HPMC maka 
konsentrasi air didalam gel semakin rendah sehinggah mempengaruhi daya sebar. Terjadi perbedaan daya sebar antara sebelum dan sesudah penyimpanan diakibatkan oleh suhu penyimpanan yang tidak stabil sehingga mempengaruhi stabilitas polimer HPMC sehinggah menyebabkan kandungan air didalam gel berkurang maupun bertambah karna bertambahnya kelembapan didalam gel. Tetapi dari ketiga konsentrasi yang digunakan konsentrasi (3\%) yang memenuhi syarat karna menurut Garg et al. (2002), dimana syarat dari daya sebar gel yaitu $5-7 \mathrm{~cm}$.

\section{Uji Daya Lekat}

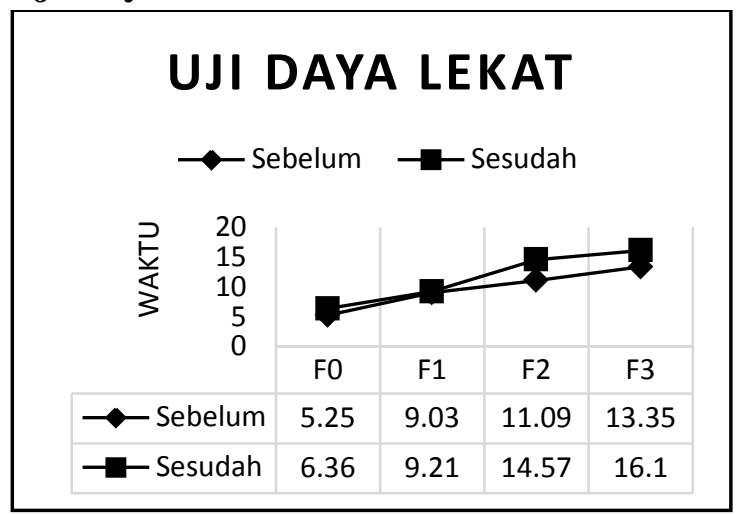

Gambar 3. Kurva Regresi Liniear Antara Konsentrasi Sediaan Gel dan Waktu

Hasil pengamatan uji daya lekat sediaan gel ekstrak etanol daun sesewanua dengan variasi konsentrasi HPMC menunjukkan semakin tinggi konsentrasi HPMC dalam suatu gel semakin lama pula kemampuan suatu gel melekat di kulit. Hasil sebelum dan sesudah penyimpanan terjadi perbedaan dimana hasil sesudah penyimpanan waktu gel lebih lama dikarenakan suhu penyimpanan yang berubah-rubah sehingga menyebabkan kadar air di dalam gel berkurang dan membuat daya lekat gel semakin besar. Semakin lama kamampuan gel melekat dikulit maka semakin bagus kualitas sediaan gel tersebut. Dimana gel antioksidan ekstrak etanol daun sesewanua engan 3 variasi konsentrasi HPMC memunhi syarat karna lebih dari 1 detik.

\section{Pengujian Efektivitas Antioksidan}

Tabel 2. Hasil Pengamatan Sediaan Gel Antioksidan Sebelum Penyimpanan

\begin{tabular}{|c|c|c|c|}
\hline $\begin{array}{c}\text { Konsentrasi } \\
(\mathbf{m g} / \mathbf{L})\end{array}$ & $\begin{array}{c}\text { Absorb } \\
\text { ansi }\end{array}$ & Grafik & $\begin{array}{c}\mathbf{I C}_{\mathbf{5 0}} \\
(\mathbf{m g} / \mathbf{L})\end{array}$ \\
\cline { 1 - 2 } $\mathbf{5 0}$ & 0,657 & & \\
\cline { 1 - 2 } $\mathbf{1 0 0}$ & 0,599 & \multirow{2}{*}{$\begin{array}{c}\mathrm{Y}=0,104 \mathrm{x}+ \\
37,2\end{array}$} & \multirow{2}{*}{123} \\
\cline { 1 - 2 } $\mathbf{1 5 0}$ & 0,596 & $\mathrm{R}^{2}=0,9298$ & \\
\cline { 1 - 2 } $\mathbf{2 0 0}$ & 0,586 & \\
\cline { 1 - 2 } $\mathbf{2 5 0}$ & 0,503 & & \\
\hline
\end{tabular}

Tabel 3. Hasil Pengamatan Sediaan Gel Antioksidan Sesudah Penyimpanan

\begin{tabular}{|c|c|c|c|}
\hline $\begin{array}{c}\text { Konsentrasi } \\
(\mathrm{mg} / \mathrm{L})\end{array}$ & $\begin{array}{c}\text { Absorb } \\
\text { ansi }\end{array}$ & Grafik & $\begin{array}{c}\begin{array}{c}\mathrm{IC}_{50} \\
(\mathrm{mg} / \mathrm{L})\end{array} \\
\end{array}$ \\
\hline 50 & 0,657 & \multirow{5}{*}{$\begin{array}{c}\mathrm{Y}=0,182 \mathrm{x}+ \\
2,1 \\
\mathrm{R}^{2}=0,8673\end{array}$} & \multirow{5}{*}{263} \\
\hline 100 & 0,599 & & \\
\hline 150 & 0,596 & & \\
\hline 200 & 0,586 & & \\
\hline 250 & 0,503 & & \\
\hline
\end{tabular}

cycling test menunjukkan gel 3\% ekstrak etanol daun sesewanua ialah yang paling baik dan memenuhi syarat. Dan Hasil dari pengujian aktivitas antioksidan gel konsentrasi 3\% dengan metode DPPH terdapat perubahan warna pada saat pengujian dimana warna DPPH menjadi pudar bukan lagi berwarna ungu pekat. Dimana larutan jika DPPH dicampurkan dengan senyawa yang dapat mendonorkan atom hidrogen, akan menghasilkan bentuk tereduksi dari DPPH dan berkurangnya warna ungu (Molyneux, 2004).Semakin besar konsentrasi ekstrak yang ditambahkan, maka semakin baik aktivitas antioksidan sediaannya. Hal ini didasarkan pada nilai IC50 yang lebih rendah. Selain itu, dari diagram di atas dapat diketahui bahwa waktu penyimpanan berpengaruh terhadap aktivitas antioksidan sediaan. Hasil $\mathrm{IC}_{50}$ yang berbeda antara sediaan gel 
sebelum penyimpanan dan sesudah penyimpanan dimana hasil dari sebelum penyimpanan yaitu $123 \mathrm{mg} / \mathrm{L}$ dan hasil sesudah penyimpanan $263 \mathrm{mg} / \mathrm{L}$. Efektivitas antioksidan sediaan gel menurun selama penyimpanan, terlihat dari nilai IC50 yang lebih besar dari sebelum penyimpanan.Menurunnya efektivitas sediaan gel antioksidan setelah penyimpanan dapat dipengaruhi oleh faktor lingkungan misalnya cahaya yang dapat menyebabkan proses oksidasiyang dapat menurunkan aktivitas antioksidan sediaan gel. Kemudian perlakuan pada saat preparasi sampel sampai pembuatan sediaan gel dapat pula berpengaruh terhadap penurunan aktivitas antioksidan. Perlakuan yang kurang baik membuat sediaan lebih banyak kontakdengan lingkungan, sehingga dapat menurunkan aktivitas antioksidan sediaan.

\section{Kesimpulan}

Berdasarkan dari hasil penelitian yang telah dilakukan maka, dapat disimpulkan bahwa :

a. Ekstrak etanol daun Sesewanua dapat diformulasi dalam bentuk sediaan gel antioksidan (skin care).

b. Sediaan Gel Antioksidan Ekstrak Etanol Daun Sesewanua dengan konsentrasi HPMC 3\% yang paling bagus karna memenuhi persyaratan uji stabilitas dan mutu sediaan.

3. Sediaan Gel Antioksidan Ekstrak Etanol

Daun Sesewanua dengan konsentrasi HPMC $3 \%$ mempunyai $\mathrm{IC}_{50}$ sebesar $123 \mathrm{mg} / \mathrm{L}$ (sebelum penyimpanan) dan $263 \mathrm{mg} / \mathrm{L}$ (sesudah penyimpanan).

\section{Saran}

Perlu dilakukan penelitian lebih lanjut untuk sediaan gel ekstrak etanol daun sesewanua untuk uji viskositasdan uji mikrobiologi

\section{DAFTAR PUSTAKA}

Ansel, H. C. 1989. Pengantar Bentuk Sediaan Farmasi. Cetakan 1. UI Press. Jakarta

Baumann, L. dan Alleman, I.B., 2009. Antioxidants

Cosmetic

Dermatology: Principles and Practice, 2nd Ed. McGraw-Hill Professional, New York, hal. 292311.

Burda dan Olezek. 2001. Teori radikal bebas dalam gizi dan kedokteran. Cermin Dunia Kedokteran. 73:911.

Departemen Kesehatan, 1995. Materia Medika Indonesia, Jilid ke-6. Departemen Kesehatan Republik Indonesia Direktorat Jendral Pengawasan Obat dan Makanan Direktorat Pengawasan Obat Tradisional, Jakarta.

Dewi, RK. 2010. Optimasi Formulasi Mikroemulsi Sediaan Hormon Testosteron Undekanoat. Jakarta: UniversitasNegeri Islam Syarif Hidayatullah.

Garg, A., Aggarwal, D., Gang, S., Sigla, A K. 2002. Spreading of Semisolid Formulation: An Update. Pharmceutical Technology 9:(2), 84-102

Miranti, A. 2009. Tumbuhan Obat dan Khasiatnya. Penebar Swadaya: Jakarta, Hlm 73-74

Huliselan, Y., Runtuwene, M., Wewengkang, D. 2015. Aktivitas 
Antioksi dan Ekstrak Etanol, EtilAsetat, dan $n$-Heksan dari sesewanua (Clerodendron squamatum Vahl.). Jurnal Ilmiah Farmasi. 4:(3), 155-156.

Lieberman. Pharmaceutical Dosage Form: Dispersi System. Volume II. New York: Marcel Dekker, Inc. 1989.

Mackiewicz., Rimkevicius. 2008. Remingtons Pharmaceutical Scienc,18 edition. Marck Publishing Co,Easton.

Molyneux, P. 2004. The Use of The Stable Free Radical Diphenylpicrylhydrazyl (DPPH) For Estimating Antioxidant Activity. J.Sci. Technol. 26:(2), 211-219.

Sangi, M., Runtuwene, M.R.J., Simbala, H.E.I., Makang, V.M.A. 2008. Analisis Fitokimia Tumbuhan Obat di Kabupaten Minahasa Utara. Chemistry Progress. 1:(3), 47-53

Tranggono, R.I., \&Latifah, F. 2007. Buku Pegangan Ilmu Pengetahuan Kosmetik. Jakarta: PT. GramediaPustakaUtama. 